\title{
Interactive Whiteboard (IWB) Effectiveness in Vocabulary Achievement and Motivation: Saudi EFL Learners' Perceptions and Insights
}

\author{
Waqar Ahmad \\ University of Jeddah- KSA \\ waqar22@gmail.com
}

Zuraina Ali

Center for Modern Languages and Human Sciences- University Malaysia Pahang- Pekan Campus-Malaysia zuraina@ump. edu.my

\begin{abstract}
English language teaching in Saudi Arabia has witnessed an enormous change with the introduction of modern technological equipment in the preparatory year program in Saudi universities. The new generation of digital natives have certain expectations about the use of technology, such as the Interactive Whiteboard (IWB) in their EFL classrooms. The current research study conducted at a Saudi university, involving two intact groups from the preparatory year EFL learners, aimed at understanding the perceptions and insights of the learners while providing them intervention with the help of Interactive Whiteboard (IWB) for 6 weeks. The data was collected at the end of the intervention, through a Likert-scale questionnaire designed for this study. The data attained showed that Saudi EFL learners' experiences about the effects of Interactive Whiteboard (IWB) on their vocabulary achievement and their motivation were positive. Whereas the experiences of both the male and female participants were similar.
\end{abstract}

Keywords: Interactive Whiteboard(IWB),Saudi EFL learners' perceptions, motivation, vocabulary achievement.

\section{Introduction}

Modern technological tools and devices now form an integral part of the individuals' lives in the $21^{\text {st }}$ century and these tools and devices are now used for business, education, entertainment, communication, and other daily life activities. The technological tools and devices are also widely used amongst the new generations, particularly the university students. This extensive use of technological tools and devices have certainly made a huge impact on the way people learn and interact with each other. Thus, technological tools and devices have caused a revolution in the world of communication and networking and have also changed the ways people learn and access the profusion of wealth of information that surrounds them and their societies. Modern technological tools and devices have also caused a paradigm shift in education all over the globe resulting in emphasis on new parameters in education such as collaboration, personalization as well as usergenerated content.

The data and figures on the website of Communication and Information Technology Commission (CITC) Saudi Arabia confirms that the use of computers, technology and internet has shown a vertical growth. The statistical data states that in 2000; only $0.9 \%$ of the population had access to the internet and modern communication services, while in 2016 it has increased 
dramatically to $64.07 \%$ of the population. The growth verifies the claim that computers and technologies are now used in every sphere of the life, and education is not an exception.

The development of technology and computer applications has a role in educational field and especially the language learning as Beatty (2013) has mentioned. The computers before were available at research facilities on university campuses and the learners have to travel to a computer for instruction. Presently computers and modern technological equipment are available in all schools, colleges and universities. Saudi Government is spending a huge sum of money on education, which is around 13\% of the Gross Domestic Product (GDP) every year, and one of the major projects that are being undertaken at most of the educational institutions, throughout the kingdom is to uplift the classrooms by incorporating modern technologies in the classrooms.

In spite of fact that millions of dollars are being spent on the English language programs run at most of the universities as preparatory year program, the linguistic outcome suffers significantly (Elyas, 2014; Elyas \& Al Grigri, 2014; Elyas \& Picard, 2012; Mahboob \& Elyas, 2014). The lack of motivation in Saudi EFL learners is one of the major factors for the failure of the EFL programs in Saudi Arabia (Al-Khairy, 2013; Aldosari, 2014; Khan, 2011). Similarly, Saudi EFL learners' inability to grasp the appropriate and suitable vocabulary learning techniques is also considered crucial for the lack of interest in their EFL classes and their language development (Alsaif \& Milton, 2012; Guduru, 2014; Nosidlak, 2013).

Several studies have documented that computers and technologies are now essential elements of education, especially in the field of language learning and teaching (Khan, 2011; Oyaid, 2009). According to Mahdi and Al-Dera (2013) the Saudi government is committed to providing most educational institutions with computers and networking. The Education ministry is also committed to set up Learning Resources centres at the schools, colleges, and universities. The aim of setting up these centres is to enable the educational institutions to adapt technological advances and to incorporate these technological advancements in the classroom.

It is inevitable that this new generation of digital natives have certain expectations about the way they believe learning should be practiced and how it should evolve to have these technologies as an integral part of this learning process. With this fast growing and rapid change in the world of technological advancement, culture pedagogy and developments in knowledge, it is crucial for the teacher in this era to be familiar with such new educational changes, mainly those changes that relate to technology. One such addition is the integration of the Interactive Whiteboard (IWB) in the English language classrooms. An Interactive Whiteboard (IWB) is described as a system made up of a computer connected to a data projector and a board. It is a large, touch-sensitive, interactive display system that formulate a connection between a teaching platform and a projector and computer (Miller \& Glover, 2010; Vita, Verschaffel, \& Elen, 2014). Along with it, the Interactive Whiteboard (IWB) being touch sensitive, displays the projected illustrations, and allows the teachers and students to control and manipulate them. According to Durán and Cruz (2011) a normal Interactive Whiteboard (IWB) has the capability to transfer data from the board to the computer immediately after the screen is touched.

With these challenges in mind and the fact that modern day technologies have gained recognition globally for their success in supporting second language acquisition, Ministry of Higher Education in Saudi Arabia aspire to provide most educational institutions with modern equipment for integrating technology into the EFL classrooms. Several studies conducted to understand the role of Interactive Whiteboard (IWB) have revealed positive attitudes of the teachers and students (Jelyani, Janfaza, \& Soori, 2014; Rajabi \& Khodabakhshzadeh, 2015). The researchers have also suggested that it increased interest and motivation among students and teachers (Hockly, 2013; Vita et al., 2014). However, a thoughtful review of the available literature has revealed the point that these studies were limited to the teachers and learners' perceptions; and the value of Interactive Whiteboard (IWB) in the teaching and learning process (Balta \& Duran, 2015; Ersoy \& Bozkurt, 2015; Jelyani et al., 2014; Rajabi \& Khodabakhshzadeh, 2015). The current research study thus, 
endeavoured to understand the perceptions of the Saudi EFL learners about the effects of Interactive Whiteboard (IWB) on the EFL learners' vocabulary achievement and motivation while studying English at a Saudi university preparatory year program.

\section{Literature Review}

Since the advent of 21st century, computers and technologies have significant role in the field of English language teaching and learning. Several studies have been undertaken concerning the role of different technologies in ELT and that how it affects the development of language. It has been found by researchers that the use of technology inside or outside the EFL classroom tends to make the class more interesting. The researchers have also suggested that using a variety of technological materials has been shown to increase student interest and motivation. Generally, the literature that has been reviewed for this study tells us that both the teachers and students have positive attitude and beliefs about the role of Interactive Whiteboard (IWB) in the process of foreign language teaching.

A study by Mathews-Aydinli and Elaziz (2010) determined the attitudes and beliefs of EFL learners and teachers in Turkey on the use of Interactive Whiteboard (IWB). Researchers have reported that both the students and teachers have shown positive attitudes towards the use of Interactive Whiteboard (IWB). The teachers and the students ensured strong belief about the usefulness of this technology and thus recommended the extensive us of this technology in the teaching and learning process. A similar kind of study was conducted by Durán and Cruz (2011) and they have concluded that when the teachers used the Interactive Whiteboard (IWB) during their lessons were more liked by the learners as the learners marked those lessons to be thrilling and exciting and that learners were feeling more motivated. Similarly, the findings of a study by Barber, Cooper, and Meeson (2007) confirmed the results of the studies mentioned earlier. The authors stated that the Interactive Whiteboard (IWB) when utilized in the classrooms, helped to boost, motivate and encourage the learners. Several students also favoured the technology as it helped them in refining their handwritings.

Correspondingly, a study by Sadeq, Akbar, Taqi, and Rajab (2016) also explored the influence of Interactive Whiteboard (IWB) on the language usage of a primary school students as perceived by teachers in Kuwait. The study also explored the obstacles that hinder the implementation of the Interactive Whiteboard (IWB). The assumptions drawn by the researchers of this study showed that although the teachers produced occasions for the children to engage in physical contact with the board by taking advantage of audio-visual aid presentations, the opportunities to take part in the dialogic interaction beyond the production of one or two-word utterances were limited. The researchers concluded that using the Interactive Whiteboard (IWB) in the teaching and learning process is a hindering rather than an aiding tool.

Similarly, a research conducted by Shams and Ketabi (2015) explored the perceptions of teachers and students of the effectiveness of the Interactive Whiteboard (IWB) in the teaching and learning process in Iran and it has been concluded that it plays a positive role and should be incorporated in the teaching and learning process in the classrooms. Instead Schmid (2016) and Millum and Warren (2014), have added that the progressive and positive role of the Interactive Whiteboard (IWB) in the language classrooms should not only be dedicated consecrated and dedicated only to the device or the technology, but the recognition and credit should be given to the teachers who were able to make an effective use of this technology.

Bahadur and Oogarah (2013) conducted a feasibility study to determine the learners and teachers' perceptions of the potential benefits and disadvantages of using the Interactive Whiteboard (IWB) in the teaching and learning environments in Mauritius. Data for the learners' perspectives was gathered from 3 classes of 2 different schools, where Interactive Whiteboard (IWB) was used by conducting the pre-test and post-treatment surveys. While the data for the teachers' perspective was collected by administrating questionnaires to 125 teachers in 13 primary schools. The data analysis 
of the learners' data found no major difference between the learners who learned with the Interactive Whiteboard (IWB) and those who studied with the traditional pen and paper method. However, the data collected from teachers showed that most of the teachers considered Interactive Whiteboard (IWB) to be an effective tool which can benefit all types of learners. The data also portrayed that Interactive Whiteboard (IWB) has a positive effect on the attention and motivation of the learners as the students always welcome the new technology. However, it should be noted that the study has based its results on the assumptions of the teachers and during the study it has been found that some of the teachers have used the Interactive Whiteboard (IWB) for a very short duration of their class time. The study is based on the perceptions of the learners and teachers mainly from the primary schools, however, the current study is based on the university adult students. Meanwhile, the current study has focused mainly on the EFL learners' perspective by conducting a thorough investigation. Also, in the current study, Interactive Whiteboard (IWB) has been used for learners for the whole duration of the treatment time, i.e. six (6) weeks.

A study carried out by Toscu (2013) explored the connection between classroom interaction and Interactive Whiteboard (IWB) use in EFL classes at tertiary level in Turkey. The researcher matched the types of interaction patterns that appeared in both types of classes; the first one equipped with Interactive Whiteboard (IWB) and the second one with just conventional whiteboards. Her results showed that there were not any significant differences of interaction patterns between the two groups of EFL learners and teachers. The results suggested that the Interactive Whiteboard (IWB) technology on their own does not illustrate any decisive role in stimulating classroom interaction for EFL learners. According to Hockly (2013) there is not much reference to any specific improvements in student attainment due to the use of the Interactive Whiteboard (IWB) in the language classroom. This statement is also supported by the findings of some researchers who report that students and teachers have to develop positive attitudes toward the use of Interactive Whiteboard (IWB) (Türel and Johnson, 2012; Türel, 2011) and that it increases interest and motivation among students and teachers (Johnson, Ramanair, \& Brine, 2010; Mathews-Aydinli \& Elaziz, 2010).

Türel and Johnson (2012) in their study surveyed teachers' opinions about the use of Interactive Whiteboard (IWB) technology for teaching and learning in Turkish primary and high schools. The results of their study have shown that in order to facilitate learning and instruction teachers should use the Interactive Whiteboard (IWB) in their classrooms on regular and systematic basis. They further suggested that the teachers should be trained to make use of this technology more efficiently and effectively. The teachers should also collaborate among each other to learn from the experiences of other teachers. A research conducted by Xu and Moloney (2011) explored the perceptions of teachers and students of the effectiveness of the Interactive Whiteboard (IWB) technology in the teaching and learning process of Chinese language and it has been concluded that it plays a positive role and should be incorporated in the teaching and learning process in the classrooms. On the other hand, Durán and Cruz (2011) have added that the progressive and positive role of the Interactive Whiteboard (IWB) technology in the language classrooms should not only be dedicated consecrated and dedicated only to the device or the technology, but the recognition and credit should be given to the teachers who were able to make an effective use of this technology.

Several researchers have conducted their studies to understand the beliefs of the teachers and students in the language classes about the benefits and advantages of the Interactive Whiteboard (IWB) technology; however, they have reported that the teachers and students were not fully convinced about these benefits and they just considered it a tool that might be helpful in some cases. For instance, a study by Schmid and Schimmack (2010) investigated the attitudes of teachers towards the use of Interactive Whiteboard (IWB) technology in the language classrooms and the findings of the study have revealed that the participants did not find the use of Interactive Whiteboard (IWB) to be of much use as it did not bring any positive change in the attitudes of the students. The researchers have mentioned some benefits of the Interactive Whiteboard (IWB) as reported by the participants, such as the easy access and availability of the internet. But the fact is, as mentioned by researchers, 
that this feature could be achieved by a simple projector and there is no need for such an expensive tool to be installed in the classroom. A study by Coyle, Yanez, and Verdú (2010) also explored the impact of Interactive Whiteboard (IWB) on the language usage of a primary school teacher and a group of native and non-native speaker children in an English language immersion classroom. The conclusions drawn by the researchers of this study showed that although the teacher produced occasions for the children to engage in physical contact with the Interactive Whiteboard (IWB) by taking advantage of audio-visual aid presentations, opportunities to take part in the dialogic interaction beyond the production of one or two-word utterances were limited and largely restricted to the native speakers' children in the group only.

Keeping in view, the importance of technology in our everyday life and also the standing position of the Interactive Whiteboard (IWB) in the present educational contexts, researchers emerge to validate the view that foreign language teachers need special training and skills in the effective use of Interactive Whiteboard (IWB) in the language classroom. According to Schmid and Schimmack (2010) a major impediment to the utilization of technology such as Interactive Whiteboard (IWB) in foreign language classrooms is the fact that the language teachers are not sufficiently trained to integrate the technology into their language teaching and learning activities. Most of the training sessions provided for language teachers on the integration of technology are usually one-day workshops which neither accord the teachers sufficient time to learn nor offer follow-up services to the school and classroom levels. This view is supported by Tosuntaş, Karadağ, and Orhan (2015) who investigated the new competencies that EFL teachers need to acquire in order to be able to use Interactive Whiteboard (IWB) to develop their practice. The results of her study demonstrated that various competencies are required to integrate the technology into teaching: (a) the ability to design Interactive Whiteboard (IWB)-based materials which support opportunities for learner interaction with the Interactive Whiteboard (IWB) and with the learning content; (b) the appropriate management of interaction around Interactive Whiteboard (IWB) in a way that ensures all learners are provided with opportunities to become actively involved; and (c) the ability to find the 'right balance' of technology use. This means that investment in good-quality teacher training is essential and especially pre-service language teacher education programs play a central role in enabling teachers to use the Interactive Whiteboard (IWB) technology towards a socio-cognitive approach to technology enhanced language teaching. On these grounds, it can be argued that training for Interactive Whiteboard (IWB) use should start in pre-service foreign language teacher education programs and continue in in-service training programs.

An extensive review of the available literature Interactive Whiteboard (IWB) in major research databases revealed that there was a scarcity of research in the field of Interactive Whiteboard (IWB) in EFL and Saudi context. As far as the studies on Interactive Whiteboard (IWB) are concerned, the majority of the previous studies had some limitation either in terms of sampling, some of these studies were conducted at school levels, while other used a very small sample size, while other selected only junior or secondary high school students. Even, no such research has been found in the available reviewed literature that corresponds to the effects of Interactive Whiteboard (IWB) on EFL learners' motivation and vocabulary achievement while learning English as a foreign language. In fact, there is not enough empirical research evidence regarding the effectiveness of the Interactive Whiteboard (IWB) technology in foreign language teaching and learning. The current study thus tends to apprehend the perceptions of the PYP Saudi EFL learners about the effects of Interactive Whiteboard (IWB) use in EFL classrooms on learners' motivation and vocabulary achievement at a Saudi university. 


\section{Research Questions}

The key research questions under investigation in this study are:

1. How do EFL learners' experience the use of Interactive Whiteboard (IWB) and its impact on their vocabulary achievement and their motivation?

2. Is there any significant difference between the male and female EFL learners' experiences about the effects of Interactive Whiteboard (IWB) on their vocabulary achievement and motivation?

\section{Methodology}

The research study was undertaken with the preparatory year program (PYP) students at a public-sector university in Kingdom of Saudi Arabia. Due to the separate university campuses for male and female students in Saudi Arabia, an equal proportion of male and female EFL learners were included in the study for the collection of data. Two intact groups of the PYP students enrolled in Pre-Intermediate level were selected, one from the male campus and the other from the female campus. The use of the intact group according to Creswell (2012), is undertaken in situations when the researcher does not have full control to make their own group. In the current research study, the groups are already formulated by the university management, and therefore intact groups were used to serve the purpose of the study. Thus, the study included 62 EFL learners of the PYP enrolled in Pre-Intermediate level. 31 students were in the male group while another 31 students were in the female group.

This investigation explored the Saudi EFL learners' perceptions and insights about using the Interactive Whiteboard (IWB) and its impact on learners' motivation and achievement, and for that purpose a questionnaire was used. The researcher studied and evaluated Dörnyei and Ushioda (2011) where a number of research instruments investigating motivation has been provided. The researcher also evaluated other questionnaires used in the studies that examined the relationship of certain computer applications and their impact on the motivation of EFL learners, such as Al-Khairy (2013), Alzayid (2012), and Javid, Al-Asmari, and Farooq (2012); however, no instrument was found to be appropriate that could cover the scope of the current study. The researcher therefore developed a questionnaires for the context of the current study, keeping in view the guidelines from Dörnyei and Ushioda (2011).

Oppenheim (2000) emphasises the advantages of using a questionnaire and explains that as an instrument, questionnaire needs little time, there is no extended writing, it is easy to process, makes group comparisons easy, and is useful for testing specific hypothesis. Likert-scale items were used to collect the data which according to Turner (1993) are a useful and effective mean of determining opinions and attitudes. According to Dörnyei and Taguchi (2010), the Likert scale is the most common used scaling technique, as the number of research studies employing this technique has certainly reached a six-digit figure, and which is due to the fact that the method is simple, versatile and reliable.

The purpose of questionnaire was to explore the perceptions of the Saudi EFL learners about the effects of the Interactive Whiteboard (IWB) on EFL learners' achievement and motivation; therefore, it was considered essential to provide intervention to the learners with Interactive Whiteboard (IWB). And for that purpose, the EFL learners in both the groups were taught the course book with the help of the Interactive Whiteboard (IWB). The duration of the module is 6 weeks, so the Interactive Whiteboard (IWB) was used for the whole duration of the module and the teachers teaching these two groups were provided necessary training to use the Interactive Whiteboard (IWB) in their classes effectually.

The questionnaire used in the study, consisted of four (4) background items about the participants' gender, faculty, age, and level of study and 26 Likert type items, for which the scale of 
1 to 6 (Strongly Disagree to Strongly Agree) were used. The 26 Likert type items in questionnaire are divided into four (4) sections. The first section is about the dimensions of learning; the second section about the effectiveness of Interactive Whiteboard (IWB) when learning vocabulary; the third section about learners' motivation; and the fourth section about findings regarding the difference from traditional whiteboard. To provide necessary help and scaffolding to the participants of the study in understanding the statements in the questionnaire, it was translated into the participants native language, with the help of two (2) colleagues. Thus, the Arabic versions of the questionnaires were administered to both of the male and female groups after they have completed studying with the help of Interactive Whiteboard (IWB). The questionnaire was validated in terms of contents or face validity and also construct validity, by two (2) lecturers from the public sector university in Saudi Arabia. Moreover, Cronbach alpha was used to measure the internal consistency of the questionnaire, and it was calculated as $(\alpha=0.891)$ which means that the instrument was found reliable. The data collected through the questionnaires was analysed through the Statistical Packages for Social Sciences (SPSS) for Windows v20.

\section{Results and Analysis}

This research set out to understand the perceptions and attitudes of the Saudi EFL learners about the effects of the Smartboard on the EFL learners' vocabulary achievement and motivation at a Saudi university. All the EFL learners involved in the study belonged to the preparatory year program which is a pre-requisite for all the university students to complete before they could be admitted to the faculty for their four-year graduation program.

Research question 1 is related to the experience of the EFL learners about the use of Interactive Whiteboard (IWB). In order to explore the perceptions and attitude of the EFL learners about the effects of the Interactive Whiteboard (IWB) on their vocabulary achievement and their motivation, a questionnaire was administered at the end of the study. To comprehend the attitudes and perceptions of the EFL learners about the effects of Interactive Whiteboard (IWB), descriptive statistics of the frequency percentage of different responses of the participants of the study are presented in Table 1.

Table(1): Descriptive Statistics

\begin{tabular}{|l|l|l|l|l|l|l|l|}
\hline Frequency \% & N & $\begin{array}{l}\text { Strongly } \\
\text { Disagree (1) }\end{array}$ & Disagree (2) & $\begin{array}{l}\text { Slightly } \\
\text { Disagree (3) }\end{array}$ & $\begin{array}{l}\text { Partly } \\
\text { Agree } \\
\text { (4) }\end{array}$ & $\begin{array}{l}\text { Agree } \\
(\mathbf{5})\end{array}$ & $\begin{array}{l}\text { Strongly } \\
\text { Agree (6) }\end{array}$ \\
\hline Male Participants & 31 & 3.47 & 9.68 & 12.53 & 24.69 & 30.27 & 19.35 \\
\hline Female Participants & 31 & 3.10 & 8.44 & 12.16 & 23.95 & 31.76 & 20.60 \\
\hline All Participants & 62 & 3.29 & 9.06 & 12.34 & 24.32 & 31.02 & 19.98 \\
\hline
\end{tabular}

To understand the results of the questionnaire in a more simplified way, the overall negative and positive responses are combined under one heading. Thus, the responses from 'Strongly disagree' to 'Slightly disagree' are all combined under overall negative responses and responses from 'Partly agree' to 'Strongly agree' are combined under overall positive responses. Table 2 exhibits the summary percentages of participants' responses on questionnaire. The overall positive responses rate or the overall percentage of agreement responses was $75.31 \%$. On the other hand, $24.69 \%$ of the participants reported their disagreement respectively. The summary percentages of the responses of the participants to questionnaire indicated that majority of the participants agreed to the statements in questionnaire. Only 25 percent of the participants expressed their disagreement to the statements in questionnaire. 
Table(2): Frequency Percentage of Male and Female participants

\begin{tabular}{|l|l|l|l|}
\hline Frequency\% & $\mathbf{N}$ & Overall Negative Responses & Overall Positive Responses \\
\hline & & $\begin{array}{l}\text { (From Strongly Disagree to Slightly } \\
\text { Disagree) }\end{array}$ & (From Partly agree to Strongly Agree) \\
\hline Male students & 31 & 25.68 & 74.32 \\
\hline Female Students & 31 & 23.70 & 76.30 \\
\hline All Participants & 62 & 24.69 & 75.31 \\
\hline
\end{tabular}

Nevertheless, the responses of both of the male and female EFL learners involved in the study, were similar. Overall $25.68 \%$ of the responses of the male students were in the zone of 'Strongly disagree' to 'Slightly disagree', whereas $74.32 \%$ of the responses were in the zone of 'Partly agree' to 'Strongly agree'. On the other hand, the responses of the female students that fell in disagreement zone were $23.70 \%$, whereas $76.30 \%$ were in the zone of agreement. This clearly advocates the similarities in the experiences of the EFL learners about the effects of the Interactive Whiteboard (IWB) on their vocabulary achievement and their motivation.

As discussed earlier, the questionnaire focused four (4) major themes, that were closely related to the focus and objectives of the study and thus Table 3 illustrates a detailed analysis of the four (4) different sections of the questionnaire. The first section was about the findings regarding the dimensions of learning; the second section about the effectiveness of Interactive Whiteboard (IWB) when learning vocabulary; the third section about findings regarding learners' motivation; and the fourth section about findings regarding the difference from traditional whiteboard.

Table(3): Detailed analysis of Questionnaire

\begin{tabular}{|l|l|l|l|l|l|l|l|}
\hline Frequency \% & $\mathbf{N}$ & $\begin{array}{l}\text { Strongly } \\
\text { Disagree (1) }\end{array}$ & $\begin{array}{l}\text { Disagr } \\
\text { ee (2) }\end{array}$ & $\begin{array}{l}\text { Slightly } \\
\text { Disagree } \\
(\mathbf{3})\end{array}$ & $\begin{array}{l}\text { Partly } \\
\text { Agree } \\
\mathbf{( 4 )}\end{array}$ & $\begin{array}{l}\text { Agree } \\
\mathbf{( 5 )}\end{array}$ & $\begin{array}{l}\text { Strongly } \\
\text { Agree (6) }\end{array}$ \\
\hline Dimensions of Learning & 62 & 3.83 & 8.67 & 10.48 & 24.40 & 33.27 & 19.35 \\
\hline $\begin{array}{l}\text { Effectiveness of IWB in } \\
\text { learning Vocabulary }\end{array}$ & 62 & 1.61 & 11.83 & 13.98 & 24.73 & 28.76 & 19.09 \\
\hline Learners Motivation & 62 & 2.42 & 6.72 & 9.68 & 26.88 & 32.26 & 22.04 \\
\hline Difference from traditional WB & 62 & 5.11 & 9.14 & 15.86 & 21.24 & 29.03 & 19.62 \\
\hline
\end{tabular}

While Table 4 demonstrates the overall positive and negative frequencies of the four (4) sections.

Table(4): Detailed analysis of Positive and Negative frequency percentage

\begin{tabular}{|l|l|l|l|}
\hline Frequency\% & N & Overall Negative Responses & Overall Positive Responses \\
\hline Dimensions of Learning & 62 & 22.98 & 77.02 \\
\hline $\begin{array}{l}\text { Effectiveness of IWB in } \\
\text { learning Vocabulary }\end{array}$ & 62 & 27.42 & 72.58 \\
\hline Learners Motivation & 62 & 18.82 & 81.18 \\
\hline $\begin{array}{l}\text { Difference from traditional } \\
\text { WB }\end{array}$ & 62 & 30.11 & 69.89 \\
\hline
\end{tabular}

The comparison of the positive and negative responses of the EFL learners of experimental group indicates that the positive responses rate or the percentage of agreement responses for all the four sections was $75.31 \%$ (where positive responses rate for learners' motivation was $81.18 \%$, the highest positive responses rate). On the other hand, overall $24.69 \%$ of the participants reported their disagreement respectively (where the negative response rate for the difference from the traditional whiteboard was $30.11 \%$, which is the highest negative response rate).

The aim of the Research question 2 was to find out if there is any significant difference between the male and female EFL learners' experiences about the effects of Interactive Whiteboard 
(IWB) on their vocabulary achievement and their motivation, and therefore, the comparison of the male and female EFL learners is presented.

Table 5 shows the comparison of the male and female EFL learners experiences about the effects of Interactive Whiteboard (IWB) on their vocabulary achievement and their motivation.

Table(5): Mean \& Standard Deviation of the Post-treatment survey results

\begin{tabular}{|l|l|l|l|}
\hline & N & Mean & SD \\
\hline Male Participants & 31 & 4.36 & .21 \\
\hline Female Participants & 31 & 4.45 & .20 \\
\hline
\end{tabular}

The mean score of the female students 4.45 is higher than the mean score of the male students 4.36. The standard deviation for the female students is .20 whereas for the male students is .21. The statistical analysis will demonstrate if the difference between the male and female students' experiences about the effects of the Interactive Whiteboard (IWB) on their vocabulary achievement and motivation is a significant or not.

A one-way ANOVA was used to compare the mean score of the survey results of the of the male and female participants, and for that purpose, a null hypothesis was initiated:

$\mathrm{H}_{01}$ : There is no significant difference between the mean score of the male and female EFL learners' experiences about the effects of Interactive Whiteboard (IWB) on their vocabulary achievement and their motivation.

Table(6): Results of one-way ANOVA of Post-treatment survey results

\begin{tabular}{|l|l|l|l|l|l|}
\hline & Sum of Squares & df & Mean Square & F & Sig. \\
\hline Between Groups & .12 & 1 & .12 & 2.75 & .102 \\
\hline Within Groups & 2.69 & 61 & .04 & & \\
\hline Total & 2.82 & 62 & & & \\
\hline
\end{tabular}

The results of one-way ANOVA as shown in Table 6 for the questionnaire results of the male and female EFL learners establish that the difference between the two groups is not significant at 0.05 level $(\mathrm{p}=0.102>0.05)$, and consequently the null hypothesis is rejected. Thus, it can be concluded that EFL learners' experiences about the effects of Interactive Whiteboard (IWB) on their vocabulary achievement and their motivation were similar at a Saudi university.

Table 7 illustrates a detailed analysis of the male and female EFL learners' experiences about the effects of Interactive Whiteboard (IWB) on their vocabulary achievement and their motivation and demonstrate the differences between the mean score of the two groups.

Table(7): Detailed analysis of Questionnaire B

\begin{tabular}{|l|l|l|l|l|l|l|}
\hline Elements & Group & N & Mean & SD & t & Sig. \\
\hline Dimensions of Learning & Male Participants & 31 & 4.36 & .50 & 1.09 & .28 \\
\hline & Female Participants & 31 & 4.49 & .42 & & \\
\hline $\begin{array}{l}\text { Effectiveness of IWB in learning } \\
\text { Vocabulary }\end{array}$ & Male Participants & 31 & 4.36 & .46 & .24 & .81 \\
\hline & Female Participants & 31 & 4.39 & .41 & & \\
\hline Learners Motivation & Male Participants & 31 & 4.38 & .38 & 1.37 & .17 \\
\hline & Female Participants & 31 & 4.53 & .49 & & .76 \\
\hline Difference from traditional WB & Male Participants & 31 & 4.33 & .44 & .30 & .76 \\
\hline & Female Participants & 31 & 4.36 & .38 & & \\
\hline
\end{tabular}


- Dimensions of Learning: The comparison of the male and female EFL learners shows that there is a difference between the mean score of the two groups. The mean score of the female EFL learners' (4.49) is higher than the mean score of the male EFL learners' (4.36). The statistical analysis of the results shows that the difference is not significant at .05 level as $(\mathrm{p}=0.28>0.05)$.

- Effectiveness of Interactive Whiteboard (IWB) when learning Vocabulary: The comparison of the male and female EFL learners exhibits that there is a difference between the mean score of the two groups. The mean score of the female EFL learners' (4.39) is higher than the mean score of the male EFL learners' (4.36). The statistical analysis of the results shows that the difference is not significant at .05 level as $(\mathrm{p}=0.81>0.05)$.

- Learners' Motivation: The comparison of the male and female EFL learners indicates that there is a difference between the mean score of the two groups. The mean score of the female EFL learners' (4.53) is higher than the mean score of the male EFL learners' (4.38). The statistical analysis of the results shows that the difference is not significant at .05 level as $(\mathrm{p}=0.17>0.05)$.

- Difference from Traditional Whiteboard: The comparison of the male and female EFL learners discloses that there is a difference between the mean score of the two groups. The mean score of the female EFL learners' (4.36) is higher than the mean score of the male EFL learners' (4.33). The statistical analysis of the results shows that the difference is not significant at .05 level as $(\mathrm{p}=0.76>0.05)$.

Therefore, it can be concluded that there is no significant difference between the mean scores of the male and female EFL learners' experiences about the effects of Interactive Whiteboard (IWB) on their vocabulary achievement and their motivation. Majority of the participants of both the groups, i.e. male and female EFL learners reflected upon their experience of the Interactive Whiteboard (IWB) to be positive, optimistic and encouraging.

The findings of the present research study substantiate Öz (2014) investigation who conducted a study to understand the perceptions of the Turkish high school students and teachers about the use of the Interactive Whiteboard (IWB) in their English courses. Similar to the current study, Öz (2014) also used a large sample of 164 EFL students and the data was also collected by employing a questionnaire. Öz (2014) study dedicated on the four (4) themes, however, two of the themes were related to the perceptions of the EFL learners, which are perceived learning contribution, and motivation. The current study also focused on four (4) themes, and all of these are related to the EFL learners' perception and attitudes and therefore provide a more comprehensive illustration of the topic under discussion.

The present findings also support Han and Okatan (2016) who investigated the Turkish high school students attitude and experiences in EFL classrooms equipped with Interactive Whiteboard (IWB) and found positive attitudes of the students towards the Interactive Whiteboard (IWB). The authors however reported that there are some technical challenges in the Interactive Whiteboard (IWB) classrooms, such as the equipment breakdown, unavailability of the technician and other related issues. The data obtained from the questionnaire in the current study found that the EFL learners of both the groups considered the opportunity to interact and share with the Interactive Whiteboard (IWB) as the most significant and pleasant feature. The learners also reinforced the importance of Interactive Whiteboard (IWB) in increasing their motivation and confidence. The participants considered the Interactive Whiteboard (IWB) lessons as beneficial in terms of immediate opportunity to access students' knowledge and therefore perceived that the use of the Interactive Whiteboard (IWB) and its features to be effective and valuable.

Regardless of whether the EFL learners ascertain the Interactive Whiteboard (IWB) more or less positively, one result is critical and pivotal. A clear majority prefer a course that incorporate and integrate the Interactive Whiteboard (IWB) in the teaching and learning process of the English language. This is probably due to the realization of an even greater majority that the Interactive Whiteboard (IWB) benefits them to learn better and faster, and also to learn and retain vocabulary for a longer time and in a more convenient and appropriate way. Learning with the Interactive 
Whiteboard (IWB) is seen as easy as most of the participants of the study consider that it is entertaining and fun. When the questionnaire address motivation, and how learners react to it, the picture becomes impressive. Approximately, more than half of the learners reported that their motivation had increased.

\section{Conclusion}

To sum, the participants of the experimental group reported positive attitudes and perception towards the Interactive Whiteboard (IWB) use in their English classes. The participants of the current study expressed their high levels of satisfaction regarding different features of the Interactive Whiteboard (IWB). In fact, $75.31 \%$ of all the participants of the study reported positive attitudes and perceptions. Therefore, it can be concluded that the Saudi EFL learners' experiences about the effects of Interactive Whiteboard (IWB) on their vocabulary achievement and their motivation were affirmative. Majority of the participants reflected upon their experience of the Interactive Whiteboard (IWB) to be promising and encouraging.

\section{References}

[1] Al-Khairy. M. H., English as a Foreign Language Learning Demotivational Factors as perceived by Saudi Undergraduates, European Scientific Journal, 9(32)(2013), 365-382.

[2] Aldosari. H. S., The Entwined Effects of Attitude, Motivation and Gender on EFL learning: A Correlation Study, Studies in Literature and Language, 8(1)(2014), 1-5.

[3] Alsaif. A., \& Milton. J., Vocabulary Input from School Textbooks as a Potential Contributor to the Small Vocabulary Uptake Gained by English as a Foreign Language Learners in Saudi Arabia, The Language Learning Journal, 40(1)(2012), 21-33, https://doi.org/10.1080/09571736.2012.658221

[4] Alzayid. A. A., The Role of Motivation in the L2 acquisition of English by Saudi students: A Dynamic Perspective. (Unpublished Master's thesis). Southern Illinois University, Carbondale, (2012)

[5] Bahadur. G. K., \& Oogarah. D., Interactive Whiteboard for Primary Schools in Mauritius: An Effective Tool or just another Trend?, International Journal of Education and Development using Information and Communication Technology (IJEDICT), 9(1)(2013), 19-35.

[6] Balta. N., \& Duran. M., Attitudes of Students and Teachers towards the Use of Interactive Whiteboards in Elementary and Secondary School Classrooms, The Turkish Online Journal of Educational Technology (TOJET), 14(2)(2015), 15-23.

[7] Barber. D., Cooper. L., \& Meeson. G., Learning and Teaching with Interactive Whiteboards: Primary and Early years, Exeter: Learning Matters Ltd, (2007), https://doi.org/10.4135/9781446278734

[8] Beatty. K., Teaching \& Researching: Computer-Assisted Language Learning, (2nd Edition), New York: Routledge, (2013), https://doi.org/10.4324/9781315833774

[9] Coyle. Y., Yanez. L., \& Verdú. M., The impact of the interactive whiteboard on the teacher and children's language use in an ESL immersion classroom. System, 38(4)(2010), 614-625, https://doi.org/10.1016/j.system.2010.10.002

[10] Creswell. J. W., Educational Research: Planning, Conducting, and Evaluating Quantative and Qualitative Research (4th Edition), Boston: Pearson, (2012) 
[11] Dörnyei. Z., \& Taguchi. T., Questionnaires in Second Language Research: Construction, Administration, and Processing $\left(2^{\text {nd }}\right.$ ed.). New York: Taylor \& Francis, (2010)

[12] Dörnyei. Z., \& Ushioda. E., Teaching and Researching Motivation (2 ${ }^{\text {nd }}$ ed.). Harlow: Pearson Education Limited, (2011)

[13] Durán. A., \& Cruz. M., The Interactive Whiteboard and foreign Language Learning: A Case Study, Porta Linguarum, 15(2011), 211-231.

[14] Elyas. T., Exploring Saudi Arabia's EFL Student Identity: A Narrative Critical Approach, International Journal of Applied Linguistics and English Literature, 3(5)(2014), 28-38, https://doi.org/10.7575/aiac.ijalel.v.3n.5p.28

[15] Elyas. T., \& Al Grigri. W. H., Obstacles to teaching english in saudi arabia public schools: Teachers'and supervisors'perceptions, International J ournal of English Language Teaching, 2(3)(2014), 74-89,

[16] Elyas. T., \& Picard. M. Y., Towards a globalized notion of English language teaching in Saudi Arabia: A case study, Asian EFL Journal, 14(2)(2012), 99-124.

[17] Ersoy. A., \& Bozkurt. M., Understanding an Elementary School Teachers' Journey of Using Technology in the Classroom from Sand Table to Interactive Whiteboard, International Electronic Journal of Elementary Education, 8(1)(2015), 1-20.

[18] Guduru. R., An Overview of Saudi EFL Learners' Self-assessment of Vocabulary Learning Strategies, Language In India, 14(5)(2014), 242-260.

[19] Han. T., \& Okatan. S., High School Students' Attitudes and Experiences in EFL Classrooms Equipped with Interactive Whiteboards, GiST Education and Learning Research Journal, 13(2)(2016), 148-165, https://doi.org/10.26817/16925777.317

[20] Hockly.N., Interactive Whiteboards, ELT Journal, 67(3)(2013), 354-358, https://doi.org/10.1093/elt/cct021

[21] Javid. C., Al-Asmari. A. R., \& Farooq. U., Saudi Undergraduates' Motivational Orientations Towards English Language Learning along Gender and University Major Lines: A Comparative Study, European Journal of Social Sciences, 27(2)(2012), 283-300.

[22] Jelyani. S. J., Janfaza. A., \& Soori. A., Integration of Smart Boards in EFL Classrooms, International Journal of Education \& Literacy Studies, 2(2)(2014), 20-23, https://doi.org/10.7575/aiac.ijels.v.2n.2p.20

[23] Johnson. E. M., Ramanair. J., \& Brine. J., 'It's not necessary to have this board to learn English, but it's helpful': student and teacher perceptions of interactive whiteboard use, Innovation in Language Learning and Teaching, 4(3)(2010), 199-212, https://doi.org/10.1080/17501229.2010.513444

[24] Khan.I. A., Learning Difficulties in English: Diagnosis and Pedagogy in Saudi Arabia, Educational Research, 2(7)(2011), 1248-1257.

[25] Mahboob. A., \& Elyas. T., English in the Kingdom of Saudi Arabia, World Englishes, 33(1)(2014), 128142, https://doi.org/10.1111/weng.12073

[26] Mahdi. H. S., \& Al-Dera. A. S. a., The Impact of Teachers' Age, Gender and Experience on the Use of Information and Communication Technology in EFL Teaching, English Language Teaching, 6(6)(2013), 57-67, https://doi.org/10.5539/elt.v6n6p57

[27] Mathews-Aydinli. J., \& Elaziz. F., Turkish students' and teachers' attitudes toward the use of interactive whiteboards in EFL classrooms, Computer Assisted Language Learning, 23(3)(2010), 235-252. https://doi.org/10.1080/09588221003776781 
[28] Miller. D., \& Glover. D., Interactive whiteboards: A Literature Survey. In M. Thomas \& E. C. Schmid (Eds.), Interactive whiteboards for education: Theory, research and practice (pp. 1-19). New York: IGI Global, (2010)

[29] Millum. T., \& Warren. C., Sharing not Staring: 21 Interactive Whiteboard Lessons for the English Classroom ( $2^{\text {nd }}$ ed.). New York: Routledge, (2014)

[30] Nosidlak. K. M., Vocabulary Learning Strategies of the Advanced Students, Journal of Language Teaching \& Research, 4(4)(2013), 655-661, https://doi.org/10.4304/jttr.4.4.655-661

[31] Oppenheim. A. N., Questionnaire Design, Interviewing and Attitude Measurement, London: Bloomsbury Publishing, (2000)

[32] Oyaid. A., Education policy in Saudi Arabia and its relation to secondary school teachers' ICT use, perceptions, and views of the future of ICT in education, Ph.D. Thesis. University of Exeter, (2009)

[33] Öz. H., Teachers' and Students' Perceptions of Interactive Whiteboards in the English as a Foreign Language Classroom, The Turkish Online Journal of Educational Technology (TOJET), 13(3)(2014), 156-177.

[34] Rajabi. A., \& Khodabakhshzadeh. H. (2015), The Effect of Implementation of Smart Board on Iranian Lower-Intermediate EFL Learners' Reading Comprehension and their Intrinsic Motivation in Reading, Mediterranean Journal of Social Sciences, 6(4), 281-289, https://doi.org/10.5901/mjss.2015.v6n4s1p281

[35] Sadeq. T. M., Akbar. R. S., Taqi. H. A., \& Rajab. V., Interactive White Board (IWB): Luxury or Hurdle in Kuwaiti Schools, International Journal of Vocational and Technical Education Research, 2(4)(2016), $1-17$.

[36] Schmid. E. C., Interactive Whiteboards and Language Learning. In F. Farr \& L. Murray (Eds.), The Routledge Handbook of Language Learning and Technology (pp. 281-295). New York: Routledge, Interactive White Board (IWB): Luxury or Hurdle in Kuwaiti Schools, (2016)

[37] Schmid. E. C., \& Schimmack. E., First steps toward a model of interactive whiteboard training for language teachers. In M. Thomas \& E. C. Schmid (Eds.), Interactive whiteboards for education: Theory, research and practice (pp. 197-214). New York: IGI Global, (2010)

[38] Shams. N., \& Ketabi. S., Iranian Teachers' Attitudes towards the use of Interactive Whiteboards in English Language Teaching Classrooms, Journal of Applied Linguistics and Language Research, 2(3) (2015), 84-99.

[39] Toscu. S., The impact of interactive whiteboards on classroom interaction in tertiary level English as a foreign language classes. (Unpublished master's thesis). Bilkent University, Ankara, (2013)

[40] Tosuntaş. Ş. B., Karadağ. E., \& Orhan. S., The Factors Affecting Acceptance and Use of Interactive Whiteboard within the scope of FATIH Project: A Structural Equation Model based on the Unified Theory of Acceptance and Use of Technology, Computers \& Education, 81(2015), 169-178. https://doi.org/10.1016/j.compedu.2014.10.009

[41] Türel. Y. K., An interactive whiteboard student survey: Development, validity and reliability, Computers \& Education, 57(4)(2011), 2441-2450, https://doi.org/10.1016/j.compedu.2011.07.005

[42] Türel. Y. K., \& Johnson. T. E., Teachers' Belief and Use of Interactive Whiteboards for Teaching and Learning, Educational Technology \& Society, 15(1)(2012), 381-394. 
[43] Turner. J., Using Likert Scales in L2 Research, Another Researcher Comments, TESOL Quarterly, 27(4) (1993), 736-739, https://doi.org/10.2307/3587409

[44] Vita. M. D., Verschaffel. L., \& Elen, J., Interactive Whiteboards in Mathematics Teaching: A Literature Review, Education Research International, (2014), 1-16, https://doi.org/10.1155/2014/401315

[45] Xu. H. L., \& Moloney. R., Perceptions of interactive whiteboard pedagogy in the teaching of Chinese language, Australasian journal of educational technology, 27(2)(2011), 307-325, https://doi.org/10.14742/ajet.972 